\title{
The greening of industrial property developments in South Africa
}

\author{
Desire A. Greenberg \\ Jayne M. Rogerson
}

Desire A. Greenberg, University of Johannesburg, Faculty of Science, School of Geography, Environmental Management and Energy Studies, South Africa

Jayne M. Rogerson, University of Johannesburg, Faculty of Science, School of Geography, Environmental Management and Energy Studies, South Africa (Jayner@uj.ac.za)

\begin{abstract}
The greening of industrial property in the developing world context of South Africa is under examination. In particular, the focus is specifically on green property developments and planning for eco-industrial parks. The South African record on greening industrial property is situated as part of broader international scholarship and debates around eco-industrial parks. The analysis reveals South Africa currently is far behind a number of other emerging economies in terms of the making of eco-industrial parks. Driven by cost considerations and the image demands of international investors a process of the greening of industrial property developments in urban areas is taking root in the country. Nevertheless, at present there exists no eco-industrial parks using principles of industrial ecology that can parallel those in other parts of the world. Overall, it is shown that planning for ecoindustrial parks is in its infancy in South Africa.
\end{abstract}

Keywords: greening, industrial property, eco-industrial parks, South Africa

\section{Introduction}

Globally research interest around the 'green economy' has expanded particularly since the 2008 financial crisis. Notwithstanding critiques about 'green-washing' Borel-Saladin \& Turok (2013a) contend from an examination of the international experience that the greening of the economy potentially can result in substantive and transformative changes towards the goal of sustainable development. In the case of South Africa the greening of the economy has become an important policy issue for two major reasons, namely the high level of national unemployment and the high carbon impact of the economy (Borel-Saladin \& Turok, 2013b: 1 ). The country is ranked globally as the $14^{\text {th }}$ largest emitter of greenhouse gases. South Africa's current growth model is viewed as "heavily resource and energy-intensive, aggravating pressures on the environment and the threat of climate change" (MontmassonClair, 2012: 5).

The greening of the South African economy is incorporated into national economic development planning with the New Growth Path, launched in 2009, stressing the imperative to integrate green considerations into economic growth by decreasing the carbon emission of economic activities as well as actively identifying new opportunities in the green economy (Nattrass, 2011). Several analysts maintain that with its abundance of renewable resources (especially solar and wind power) South Africa is in a unique position to exploit opportunities related to the emergence of green economic development (Montmasson-Clair, 2012: Kaggwa et al. 2013). In 2011 the Green Economy Accord was formulated in response to concerns about climate change in South Africa. It represents a "green partnership: to create jobs, provide a spur for industrialisation, and help to create a sustainable future" (Department of Economic Development 2011: 3). With appropriate investments it is projected over the next 
decade that the growth of the green economy can create as much as 300000 employment opportunities in South Africa (Borel-Saladin \& Turok, 2013; Rogerson, 2014).

Among others Nhamo (2013) argues that national government has exhibited a high level of commitment, enhanced institutional structures and developed necessary legislation to support green economic development. Furthermore, in order to nurture South Africa's transition towards a green economy national government has launched the Green Fund which offers catalytic finance to project initiation, policy and research, and capacity building activities (Mohamed et al. 2014). During 2011 the National Strategy for Sustainable Development and Action Plan confirmed the green economy as a national priority for planning and development seeking to facilitate a just transition towards a resource-efficient, low carbon and pro-employment growth trajectory. Various greening initiatives are ongoing in different sectors of the economy albeit at uneven rates of progress (Nhamo, 2014). Overall, Kaggwa et al. (2013: 5) assert "the green economy in South Africa is viewed as a path to sustainable development based on its potential to address the interdependence among inclusive economic growth, social protection and natural ecosystems".

It is observed that most existing scholarship on green economy issues concentrates on Europe and North America with so far only limited attention devoted to countries of the global South (Cidell, 2012; Death, 2014). The objective in this paper is to examine one aspect of the evolution of the green economy in South Africa, namely the first moves taking place towards the greening of urban industrial property developments. Although some academic attention has been given to the greening of tourism accommodation, especially of the urban hotel sector (Rogerson \& Sims, 2012), the arena of industrial property development so far has not been documented. It is widely recognized, however, that traditional industrial estates can have serious environmental impacts on the physical, natural and social landscape (Sakr et al. 2011; Panyathanakun et al. 2013). The need was recognized for the innovation of new industrial development models and practices so that goals of sustainable development may be realized at local, regional, national and global scales (Geng et al., 2014). One international trend is towards establishing 'eco-industrial parks' in order to mitigate or avoid the negative impacts often associated with industrial zones (Côté \& Cohen-Rosenthal, 1998; Singhala \& Kapurb, 2002; Van Leeuwen et al. 2003; Zhu \& Côté, 2004; Gibbs \& Deutz, 2007; Shi et al. 2012a, 2012b; Taddeo et al. 2012; Conticelli \& Tondelli, 2013; Lowitt \& Côté, 2013; Tian et al., 2014). Veiga \& Magrini (2009: 653) assert that the establishment of such parks "is a concept that is spread in many nations as a new industrial model that can reconcile the three dimensions of sustainability: social, economic and environmental”. Gibbs et al (2005) suggest eco-industrial development as a potential "new paradigm" for local and regional development. In addition, Gibbs \& Deutz (2007) highlight the growing attention given to eco-industrial park development by national, regional and local governments in many developed countries.

This article examines the new phenomenon of the greening of industrial property in the developing world context of South Africa and specifically examines green property developments and planning for eco-industrial parks. In terms of methods and sources the paper draws together existing documentary material and reports on the greening of industrial property in South Africa, the results from field site visits, and most importantly the findings from several semi-structured interviews which were conducted during 2013 with key property stakeholders. The South African record on greening industrial property is situated as part of broader international scholarship and debates around eco-industrial parks.

\section{Eco-Industrial Parks: International Debates}

Eco-industrial parks are considered examples of the application of the principles of industrial ecology (Gibbs et al., 2005; Gibbs \& Deutz, 2007). The concept of industrial ecology emerged out of the study and appreciation of the functioning of natural ecosystems 
which demonstrate the efficient recycling of resources. As argued by Hewes \& Lyons (2008; 1330) a core "element of industrial ecology is the concept of closed loop systems where energy and waste materials are continuously recycled between geographical proximate firms". According to Panyathanakun et al. (2013: 71) industrial ecology as a concept essentially describes a "closed-loop system similar to that in nature, which is both complex and selforganised". The notion is that of recycling materials through industrial systems as they are in natural ecosystems such that the "byproducts of one process would become the feedstock of another” (Veigas \& Magrini, 2009: 654).

During the late 1990s Côté \& Cohen-Rosenthal (1998: 181) observed that whilst still "in its infancy as a study, industrial ecology is emerging as an exciting approach to the application of environmentally sustainable development”. A decade later works by Gibbs \& Deutz (2007) and by Veigas \& Magrini (2009) could reflect on the maturation of industrial ecology. Gibbs \& Deutz (2007: 1683) draw attention to "an increasing interest in industrial ecology" in recent years whereas Veigas \& Magrini (2009: 654) state that it "emerged over the years as a potential guide to create opportunities for improving environmental and business performance, and for restructuring the industrial system in compatible fashion with notions of sustainability". Applied, developed and implemented in various projects industrialized countries the concept is used to attain cleaner production and a level of sustainable growth, including through the establishment of so-termed eco-industrial estates or eco-industrial parks (Gibbs \& Deutz, 2007). The classic model of industrial symbiosis is that of Kalundborg in Denmark where a close web of water and energy exchanges emerged between the local city administration, a power plant, a refinery, a pharmaceuticals factory, a fish farm and a wallboard manufacturer (Ehrenfeld \& Gertler, 1997; Jacobsen, 2006; Gibbs \& Deutz, 2007; Veiga \& Magrini, 2009; Domenecha \& Davies, 2011; Kalundborg Symbiosis, 2011).

It is argued that the successful operations of the Kalundborg project "boosted the concept of industrial ecology and industrial symbiosis as well as promoting more practices in EcoIndustrial Parks” (Bai et al. 2014: 4). Indeed, Yu et al. (2014: 464) maintain that ecoindustrial parks "have become a policy-driven attempt to apply the principles of Industrial Ecology in specific locations". They contend the essential core of an eco-industrial park is industrial symbiosis that seeks to "engage otherwise separated industries in a collective approach to reduce their environmental impact" and to incorporate the "physical exchange of materials and by-products, shared management of common utilities and infrastructures for water, energy and waste” (Yu et al., 2014: 464). Overall, for Bai et al. (2014: 4) one essential defining feature of eco-industrial parks is "they use industrial ecology and industrial symbiosis principles to simulate natural ecological systems within industrial systems".

Scholarship around the concept of eco-industrial parks, however, has spawned a number of different definitions. In one of the earliest attempts at demarcating the concept Côté \& Hall (1995: 41) proposed that it "is an industrial system which conserves natural and economic resources; reduces production, material, energy, insurance and treatment costs and liabilities; improves operating efficiency, quality, worker health and public image; and provides opportunities for income generation from use and sale of wasted materials”. The United Nations Environment Programme applies a complex definition that eco-industrial parks are "the systems-oriented study of the physical, chemical and biological interactions and interrelationships both within industrial systems and between industrial and natural ecological systems (Bai et al., 2014: 4). Bugnar et al. (2013: 82) offer the view that eco-industrial parks "represent a special category compared to industrial parks, a category which is different from the classical ones due to the fact that they are designed in such a way so that they promote the collaboration between companies in order to reuse recyclable materials and green energy sources”. 
These distinctions between classic industrial parks or estates and eco-industrial variants were highlighted most strongly by Côté \& Cohen-Rosenthal (1998). These authors suggested 11 essential distinctions. It was argued that as compared to a classical industrial park an ecoindustrial park would be distinguished as follows:

" 1 . Define the community of interests and involve that community in the design of the park.

2. Reduce environmental impact or ecological footprint through substitution of toxic materials, absorption of carbon dioxide, material exchanges and integrated treatment of wastes.

3. Maximize energy efficiency through facility design and construction, co-generation and cascading.

4. Conserve materials through facility design and construction, reuse, recovery and recycling.

5. Link or network companies with suppliers and customers in the wider community in which the eco-industrial park is situated.

6. Continuously improve the environmental performance by the individual businesses and the community as a whole.

7. Have a regulatory system which permits some flexibility while encouraging companies to meet performance goals.

8. Use economic instruments which discourage waste and pollution.

9. Employ an information management system which facilitates the flow of energy and materials within a more or less closed-loop.

10. Create a mechanism which seeks to train and educate managers and workers about new strategies, tools and technologies to improve the system.

11. Orient its marketing to attract companies which fill niches and complement other businesses” (Côté \& Cohen-Rosenthal, 1998: 181).

In 2003 another definition of an eco-industrial park was published by Cohen-Rosenthal (2003) which importantly incorporates the requirement for enterprise networking. It was argued that an eco-industrial park now represented "a community of businesses that cooperate with each other and with the local community to efficiently share resources (information, materials, water, energy, infrastructure and natural habitat) ... leading to economic gains, gains in environmental quality and equitable enhancement of human resources for the business and local community" (cited in Gibbs \& Deutz, 2007, 1685). A broadened perspective is one of eco-industrial parks as part of the activity of eco-industrial development, an approach which is "designed to address both global and local environmental problems while contributing to the local development needs since it provides strategies to achieve greater materials and energy efficiency, environmental safety and social integrity through economies of systems integration, whereby partnerships among businesses meet common service, transportation, and infrastructure needs, and the concept adds value to businesses and communities by optimizing the use of energy, materials and community resources” (Geng et al., 2014: 1).

Over the past 20 years eco-industrial park developments have occurred in a range of countries particularly in North America and Western Europe (Côté \& Cohen-Rosenthal, 1998; Van Leeuwen et al. 2003; Eilering \& Vermeulen, 2004; Gibbs \& Deutz, 2007; Taddeo et al. 2012; Conticelli \& Tondelli, 2013). As confirmed by Veiga \& Magrini (2009) and Tian et al. (2014) the eco-industrial park concept has diffused internationally and now has spread to developing and newly industrializing nations particularly in Latin America and Asia as a way to foster sustainable development. More specifically, given that rapid industrialization has been accompanied by environmental degradation, the concept is "being considered a possible 
way to overcome environmental damage and at the same time to improve industrial and community economic and social welfare and development” (Veiga \& Magrini, 2009: 653). In recent years much interest surrounds the concept's application and the quest for eco-industrial parks in China (Lowe, 2003; Shi et al., 2012a, 2012b; Bai et al., 2014; Tian et al., 2014; Yu et al., 2014). Behind the embrace and expansion of global interest in the concept of ecoindustrial parks is the perceived benefits for local communities of increased competitiveness, the generation of additional revenues, the creation of jobs, and advantages of reducing pressures on existing infrastructure, reduced pollution and use of energy from regenerated sources (Bugnar \& Mester, 2013). This said, as a public policy tool Gibbs \& Deutz (2007: 1692) point out the central importance of ensuring collaborative behaviour between industrial and other enterprises and the building of trust and cooperative relationships which are deemed a prerequisite before firms are prepared to link processes together. In addition, Hewes \& Lyons (2008: 1339) add the importance of 'champions' who are able to bring groups of stakeholders together and motivate them to become involved in the making of eco-industrial parks.

Arguably, eco-industrial parks exist in many different forms (Gibbs \& Deutz, 2007). Indeed, Côté \& Cohen-Rosenthal (1998) stress that one of unique characteristics of the experiments with eco-industrial parks is their differentiation. In terms of the nature of property developments, however, it is clear from the international experience that an important distinction must be drawn between eco-industrial park developments which involve building upon and transforming an existing industrial park or cluster on the one hand and of greenfield property developments of eco-industrial parks which are planned and developed from scratch on the other (Veiga \& Magrini, 2009; Yu et al., 2014). There is consensus from what has been accomplished so far that most eco-industrial parks are "at an early stage of development” (Veiga \& Magrini, 2009: 660). The most recent international overview points to the conclusion that most eco-industrial parks "are at a very early stage of development because the key features of industrial ecology such as inter-firm networking and collaboration in the form of materials interchange and energy cascading are either absent or in the early planning stages” (Bai et al., 2014: 4). It is in light of this assessment that our attention turns to examine the current state of green industrial property developments in South Africa.

\section{The Greening of Industrial Property in South Africa}

In terms of discussing the greening of commercial industrial property in South Africa two sub-sections of material are presented. The first focuses on the progress made in respect of rating and the construction of individual green industrial buildings. The second turns attention back to eco-industrial parks and critically reviews the development of so-termed ecoindustrial parks in this developing world case study.

\section{Green Industrial Property}

The greening of new commercial property developments in South Africa is increasingly becoming a mainstream rather than a marginal activity. The growing propensity for developing sustainable or green building initiatives is driven mainly by cost considerations in respect of South Africa's rapidly rising charges for electricity (Rogerson \& Sims, 2012). The Green Building Council South Africa (GBCSA) constitutes the official certification body which offers the tools and information to support green building practices in South Africa. The GBCSA has developed the Green Star SA rating tools which are closely based on the rating system used by the Green Building Council of Australia (GBCA). These tools are used to assist green building practices from the design phase, construction phase, through to the operations phase (GBCSA, 2013). 
A green property in South Africa is defined as a structure which is energy efficient, resource efficient and environmentally responsible. These factors can be measured using indicators such as building design; construction materials used; recycling of waste and building materials; water efficiency; use of renewable energy and materials and socioeconomic considerations (GBCSA, 2013). Currently, the GBSCA together with the World Green Building Council are in the process of developing a rating tool category specifically for developing countries. This new rating tool would include social and economic sustainability elements designed to assist with key development challenges such as poverty, unemployment and the absence of skills (GBCSA, 2013). As GBCSA does not currently have a rating system for industrial buildings and parks, applications by industrial properties for rating are conducted using the rating tools of the GBCA (Olivier, 2013). The GBCA Industrial v1 rating tool, however, evaluates only the environmental aspects of industrial structures and the services they offer seeking to reduce the environmental impacts associated with the planning, construction and operation of industrial buildings and parks.

Only a small handful of individual industrial properties currently can be classified as green industrial properties in South Africa. The research disclosed that Growthpoint Properties, which is the largest property development company in South Africa listed on the Johannesburg Stock Exchange, has been involved in the development of three industrial buildings. This company espouses a commitment to expanding sustainable building designs and has partnered with the GBCSA to develop a green lease and an energy benchmarking tool in respect of industrial property developments. It was disclosed that the design and construction of green industrial property developments is predominantly client-driven (Labuschagne, 2013) with international companies investing in South Africa often under pressure to develop or occupy green industrial spaces. It is not surprising therefore that the first industrial facility in South Africa to receive a 5 star Green Star rating from GBCSA is for the sub-Saharan African headquarters and factory of Grundfos, the world's largest manufacturer of pumps, and based in Denmark, one of the international leaders in applications of industrial ecology.

The Grundfos property is located in Germiston in the metropolitan area of Ekurhuleni which is in Gauteng province, South Africa's economic heartland. The rating of this facility was done using the GBCA rating system guidelines for industrial facilities. The industrial space was formerly a dilapidated building that was demolished with a new building constructed using green principles. The rubble and waste material from the demolished property was removed in a responsible manner so that much of it could be recycled into the new building (Vermeulen, 2014). Important features of the green property relate to inter alia, the incorporation of timed energy-saving lights, solar panels, waterless urinals and a rainwater harvesting system. A building management system is installed to electronically monitor and control electricity. Use is made of energy-saving technologies for lighting, ventilation and water harvesting with demarcated areas for the recycling of paper, cardboard, plastics and metals (Vermeulen, 2014). The developers stress that the growing demand for green industrial properties from clients is driven both by recognition of potential cost savings and importantly of portraying a positive corporate image (Labuschagne, 2013). In this respect the location of this building is notable as it is situated between two major highways close to Johannesburg and therefore is highly visible for imaging the company. In interviews it was disclosed that further parallel individual industrial properties were planned and that the Grundfos facility "will definitely not be the last” (Labuschagne, 2013).

\section{Eco-Industrial Parks}

The study by Brent et al. (2008) is notable for opening up debates around the application of the concepts of industrial ecology in South Africa. These authors argue that the concept of 
eco-industrial parks is the most pressing and immediate application for South African conditions. Nevertheless, they contend that in South Africa the notion of eco-industrial parks is not a new phenomenon with a number of so-termed 'eco-estates' already in existence. Among a number of examples are a so-termed 'eco-industrial park' which is located between Pretoria and Hartbeespoort Dam which is owned and managed by South Africa's Nuclear Energy Corporation. This park has over 80 tenants with shared services including recycling. However, as no by-product exchanges occur this park fits classically the characteristics as listed by Côté and Cohen-Rosenthal (1998: 182) of "what some proponents have suggested eco-industrial parks are not". Arguably, several other early claimants to the status of ecoindustrial park in South Africa also can be dismissed on similar grounds. For example, the Capricorn Park near Muizenberg in Cape Town is an eco-friendly business and technology park but once again lacks the fundamental application of industrial ecology principles relating to interactions among businesses and exchange of by-products. Of note, however, is that certain industrial ecology principles have been incorporated into the planning of some Industrial Development Zones (IDZs), most notably at Coega near Port Elizabeth. This said, Brent et al. (2008) conclude that whilst the international concepts of eco-industrial park have been envisaged in such South African IDZs the ideal has not moved into practice.

At present three so-called eco-industrial parks in South Africa are in various stages of planning, development and construction, namely the Lords View Eco-Industrial Park situated in northern Johannesburg, the Chem City Eco-Industrial Park which is under development at Sasolburg $90 \mathrm{~km}$ in the southern part of the Gauteng city region, and the Limpopo EcoIndustrial Park which is still currently in the planning phase and to be constructed at Musina, a city close to the Zimbabwe-South Africa border. In each of these three examples of green industrial property developments aspects of the international characteristics of eco-industrial parks are represented.

The first example is of Lords View which is an industrial estate located on 2 million sq. metres of land at Chloorkop. The development is at a former sand quarry on land that was severely degraded and neglected. In 2008 the developers took the decision to establish a sustainably responsible eco-industrial park (Lord, 2013). Here are a number of features of design and operation which have parallels with international standards. The two most prominent are the sustainable urban drainage system (SUDS) and the waste-to-energy plant. The former are a series of water management practices which are designed to drain surface water in such a way as to offer a more sustainable approach to conventional run-off practices.

The SUDS programme was inspired by the storm water management system used at the Century City commercial property development in Cape Town. It is claimed this is the first SUDS system to be used in an industrial park. The second innovation is a waste-to-energy plant. Lords View has a strategic relationship with Enviroserve, a waste management and solutions company, which is responsible for producing 'green energy' for the park once the development is complete. A task team established by the local Ekurhuleni Municipality has been facilitating this development which is divided into two phases. The first phase, the production of methane to energy, is a simple, slow process which requires some time for methane to be produced through the decomposition of refuse. As the refuse decays, the methane from the decomposition process will be collected and utilised. The second phase, a much larger project, involves Enviroserve developing an on-site waste-to-energy plant making use of municipal solid waste. This process will involve municipal waste going directly to the plant for processing, thereby eliminating the wait associated with the decomposition process.

The tenants at Lords View have either the choice of using electricity from the national grid or of green electricity generated from the waste-to-energy plant. Other features of the Lords View development are a planned greenbelt which is to be the central area and 
incorporate a running track and seating areas. It is significant that in common with the local drivers for individual green industrial properties the major client of the Lords View park is to be the multinational Unilever. The waste products produced by the Unilever factory, consist of large quantities of milk by-products. Together with Enviroserv an anaerobic digester has been designed and will be developed on site to generate electricity through the decomposition process of the by-products. Although Lords View is striving towards eco-friendly industrial park designs, the park tenants are not obliged to follow green architectural designs. Many of the clients are most interested in the small greening initiatives such as natural pest control rather than use of pesticides. By contrast, Unilever follow the Leadership in Energy \& Environmental Design (LEED) process of sustainable design and principles as laid out by the US Green Building Council. One final observation is in relation to local community development as Lords View have partnered with the Ekurhuleni Municipality to create a skills development and local employment project to utilize local labour sourced from the proximate Tembisa township.

The second eco-industrial property development which is under construction is that of the Chem City Eco-Industrial Park (CEIP) which occupies an industrial site covering 1700000 $\mathrm{m}^{2}$. This is currently being developed by Sasol, a large South African integrated energy and chemicals manufacturer. The park is at Sasolburg which is south of Johannesburg within the greater Vaal Triangle chemical and industrial core and incorporates a number of large industries such as Sasol, Safripol, Omnia, NatRef, Samancor and Mittal Steel. Initially the land was zoned for and developed as a chemical energy and related infrastructure facility. Sasol changed the focus of the model and the new vision was to place emphasis on creating a bio-diverse park with green initiatives which would attract green companies. The image of the site was enhanced to reflect these green initiatives by making use of the recycling of on-site materials in the construction and development of civil infrastructure such as storm water drainage and sewerage systems. In addition to the green infrastructure of the project, to further reduce the carbon footprint of the site, a significant size of land consisting of a natural wetland has been dedicated to the natural environment with the reintroduction of indigenous fauna and flora. The greenbelt covers an area of $311791 \mathrm{~m}^{2}$ and comprises a natural wetland which acts as a sponge for flood water and a natural habitat. A grey water management system similar to the storm water management system is planned to be introduced. The grey water will be filtered and pumped into a storage tower for use in irrigation and other processes which do not require pure drinking water. This grey water filtration system will save 60 percent on potable water consumption for the site as a whole. Sasol is currently also exploring the possibility of a sewerage treatment facility in the future once the park is fully operational and has a higher occupancy level. A bi-methane sewerage digester is also under investigation. The idea follows the concept where solids and liquids are separated, and the liquids are treated, and the solid components are converted into compost and other useful products.

ChemCity is conveniently located across the road from the National Refinery (NatRef) and the Sasol 1 plant. The management of CEIP realized that there are a number of opportunities to create good linkages. Steam which is produced as a by-product from both of these plants, is an important commodity and many industries require steam in the production and manufacture of products. A second by-product produced by the Sasol 1 plant, is coal ash. ChemCity is currently exploring the viability of creating ash bricks through compaction and chemical agglomeration. A third by-product produced by the Sasol 1 plant is plastic and polymer waste. This waste has been used already to construct a building on the CEIP site which is entirely made of plastic. The park has generated a large amount of interest from recycling companies, and CEIP currently are in negotiations with two companies to provide these businesses with business development support services and access to raw materials in order to develop the market linkages. In addition, a business incubator is being established on 
site that will deliver a variety of business development support services and enterprise development support services for local community development. These services will be offered to small enterprises and entrepreneurs who wish to become suppliers to the large companies in the area. However, several barriers need to be overcome regarding the development of the CEIP project, most importantly the financial viability of such a project and the lack of communication and collaboration between companies with often opposing visions (Wyeth, 2013). Although it is acknowledged that it will be a long time before CEIP will break even financially Sasol (and ChemCity), see this project as an important contribution to support local economic development (Wyeth, 2013).

The third eco-industrial park is the Limpopo Eco-Industrial Park (LEIP) which currently is in the planning phase. The vision for the LEIP is to develop a superior industrial facility which incorporates social and environmental sustainability principles and offers services such as clean electricity generation; water treatment and solid waste management facilities with the additional benefit of downstream beneficiation of all stakeholders in an environmentally and socially sustainable manner (EIS, 2013). The park will be located in the vicinity of the city of Musina in the Limpopo province of South Africa (Du Toit, 2013). The LEIP will consist of five separate plants, which are planned to form a closed loop or symbiotic system. These plants will include a waste water treatment plant; a brick making plant; a plasma waste gasification plant; a gas-to-liquids plant; and a coke and co-generation power plant (EIS, 2013). According to Du Toit (2013) barriers to a project of this magnitude include balancing the correct combination of characteristics such as site suitability, environmental factors, existing infrastructure, value chain of feedstock and products, technological and economic viability, services, and proximity to a potential labour force. Overall the LEIP is planned to be an example of sustainable eco-industrial development and contribute to the local economy through social upliftment and sustainable resource use (EIS, 2013).

Overall the interviews confirmed that the concept of eco-industrial park is still relatively new in South Africa and currently there is no single complete and operational park in the country (Wyeth, 2013). The South African case studies exhibit a strong and distinctive focus on contributing to local economic development, employment opportunities, and skills development. In all three parks there are contributions to local community development in the form of local labour preferences, small enterprise support initiatives and training. Arguably, as yet no so-termed eco-industrial park in South Africa can claim to have embraced the critical international criteria of a community of manufacturing businesses together exhibiting collaborative behaviour for collective benefit through green design as well as the exchange of by-products with the objective of mutual benefit to the community, economy and environment (cf. Côté \& Cohen-Rosenthal, 1998; Lowe, 2001; Tudor et al. 2007; Hewes \& Lyons, 2008; Veiga \& Magrini, 2009).

\section{Conclusion}

It has been shown that greening the economy can have considerable positive impacts to stimulate growth as well as improve the environment (Borel-Saladin \& Turok, 2013a, 2013b). Tapping into this potential is of particular importance for a country such as South Africa with its high levels of unemployment as well as carbon emissions. In common with other emerging economies South Africa faces the challenge of reorienting its economy towards a low-carbon trajectory (Kaggwa et al., 2013). From the side of national government a number of innovative policy initiatives have been launched such that the country is sometimes viewed as a global leader in green economic development (Death, 2014).

This paper has examined one facet of the unfolding of green economic development in South Africa, namely the issue of the greening of urban industrial commercial property development. The analysis reveals that South Africa is presently behind a number of other 
emerging economies where considerable progress has been made towards the making of ecoindustrial parks. Driven by cost considerations and the image demands of international investors a process of the greening of industrial property developments in urban areas is taking root in the country. Nevertheless, at present, there is no advanced eco-industrial parks using principles of industrial ecology that can parallel those in other parts of the world. It is revealed therefore that planning for eco-industrial parks still is in its infancy in South Africa. A number of property developments currently are being rolled out and others are in the planning stage. Further research and monitoring is needed in order to track the progress of these unfolding developments concerning the greening of industrial property in South Africa.

\section{Acknowledgements}

Thanks are extended to the study interviewees as well as the critical inputs offered by Mabel Black, Skye Norfolk and Teddy Norfolk.

\section{References}

Bai, L., Qiao, Q., Yao, Y., Guo, J. \& Xie, M. (2014). Insights on the development progress of National Demonstration eco-industrial parks in China. Journal of Cleaner Production, 70, pp. 4-14.

Borel-Saladin, J.M., \& Turok, I.N. (2013a). The green economy: Incremental change or transformation? Environmental Policy and Governance, 23 (4), pp. 209-220.

Borel-Saladin, J.M., \& Turok, I.N. (2013b) The impact of the green economy on jobs in South Africa. South African Journal of Science, 109 (9/ 10).

Brent, A.C., Oelofse, S. and Godfrey, L. (2008) Advancing the concepts of industrial ecology in South African institutions. South African Journal of Science, 104 (1/2).

Bugnar, N. \& Mester, L.E. (2013). Eco-industrial park - A tool for sustainable development. Annals of the University of Oradea , Economic Science Series, 22(1) 82-88.

Cidell, J. (2012). Building quality, building green: Conventions theory and industry transformation. Urbani izziv, 23(supplement 2), pp. 186-194.

Cohen-Rosenthal, E. (2003). What is eco-industrial development? In E. Cohen-Rosenthal \& J. Munsikow (eds) Eco-industrial Strategies: Unleashing synergy between economic development and the environment. Sheffield, Greenleaf, pp. 14-29.

Conticelli, E. \& Tondelli, S. (2012). Application of strategic environmental assessment to eco-industrial parks: Raibano case in Italy. Journal of Urban Planning and Development, 139 (3), pp. 185-196.

Côté, R.P. \& Cohen-Rosenthal, E. (1998). Designing eco-industrial parks: A synthesis of some experiences. Journal of Cleaner Production, 6, pp. 181-188

Côté, R.P \& Hall, J. (1995). Industrial parks as ecosystems. Journal of Cleaner Production, 3 (1-2), pp. 41-46.

Death, C. (2014). The green economy in South Africa: Global discourses and local politics. Politikon, 41, pp. 1-22.

Department of Economic Development (2011). Accord 4: Green Economy Accord. Pretoria: DED.

Domenecha, T., \& Davies, M. (2011). Structure and morphology of industrial symbiosis networks: The case of Kalundborg. Procedia - Social and Behavioral Sciences, 10, pp. 79-89.

Du Toit, P. (2013). Interview CEO Eco-Industrial Solutions (PTY) Ltd. Limpopo EcoIndustrial Park Project.10 October.

Ehrenfeld, J., \& Gertler, N. (1997): Industrial ecology in practice: The evolution of interdependence at Kalundborg. Journal of Industrial Ecology, 1(1), pp. 67-79. 
Eilering, J.A.M. \& Vermeulen, W.J.V. (2004). Eco-industrial parks: Toward industrial symbiosis and utility sharing in practice. Progress in Industrial Ecology, 1 (1-3), pp. 245270.

EIS (Eco Industrial Solutions). (2013): The Limpopo Eco-Industrial Park. Available from: http://eco-industrialsolutions.com/index.php/projects/leip-cat (Accessed 20 July 2013).

GBCA (Green Building Council of Australia). (2013). Green Star - Industrial v1. Available from: http://www.gbca.org.au/green-star/rating-tools/green-star-industrial-v1/2877.htm (Accessed: 30 September 2013).

GBCSA (Green Building Council of South Africa). (2013). Leading the transformation of the South African property industry to environmental sustainability. Available from: http://www.gbcsa.org.za/ (Accessed 30 September 2013).

Geng, Y., Fujita, T., Park, H-S., Chiu, A. \& Huisingh, D. (2014). Towards post fossil carbon societies: Regenerative and preventive industrial development. Journal of Cleaner Production, DOI 10.1016/j.jclepro2013.12.089.

Gibbs, D. \& Deutz, P. (2007). Reflections on implementing industrial ecology through ecoindustrial park development. Journal of Cleaner Production, 15, pp. 1683-1695.

Gibbs, D., Deutz, P. \& Proctor, A. (2005). Industrial ecology and eco-industrial development: A potential paradigm for local and regional development. Regional Studies, 39 (2), pp. 171-183.

Growthpoint Properties (2010). Growthpoint Properties. Available from: http://www.growthpoint.co.za/Pages/AboutGrowthpoint.aspx\# (Accessed 16 October 2013).

Hewes, A.K. \& Lyons, D.I. (2008). The humanistic side of eco-industrial parks: Champions and the role of trust. Regional Studies, 42 (10), pp. 1329-1342.

Jacobsen, N.B. (2006). Industrial symbiosis in Kalundborg, Denmark: A quantitative assessment of economic and environmental aspects. Journal of Industrial Ecology, 10(12), pp. 239-255.

Kaggwa, M., Mutanga, S.S., Nhamo, G. and Simelane, T. (2013). South Africa's Green Economy Transition: Implications for Reorienting the economy towards a low-carbon growth trajectory. Johannesburg; South African Institute of International Affairs Occasional Paper 168.

Kalundborg Symbiosis (2011): Kalundborg Symbiosis is the world's first working industrial symbiosis. Available from: http://www.symbiosis.dk/en (Accessed 20 March 2013).

Labuschagne, L. (2013): Interview, Industrial Development Manager, Growthpoint Properties Development Division. 23 October, Sandton.

Lord, W. (2013). Interview Project Manager, Lord Trust Developers, Lords View Industrial Park. 22 July, Chloorkop.

Lowe, E.A. (2001). Eco-Industrial Park Handbook for Asian Developing Countries. A Report to Asian Development Bank, Environment Department, Indigo Development, Oakland, CA.

Lowe, E. (2003): Eco-Industrial development in Asian Developing Countries: Eco-chains in China: the Guitang Group. In Cohen-Rosenthal, E., and Musnikow, J. (Eds.), Ecoindustrial Strategies: Unleashing Synergy between Economic Development and the Environment (pp. 349-52). Sheffield, Greenleaf.

Lowitt, P. \& Côté, R. (2013). Putting the Eco into Eco Parks. Journal of Industrial Ecology, 17 (3), pp. 343-344.

Mohammed, N., Maitho, E., Maskiveni, E., Fourie, R., Tilly, M. \& Zondi, N. (2014). The Green Fund of South Africa: Origins, establishment and first lessons. Development Southern Africa, DOI 10.1080/0376835X.2014.935295 
Montmasson-Clair, G. (2012). Green Economy Policy Framework and Employment Opportunity: A South African Case Study. Pretoria: Trade and Industrial Policy Strategies Working Paper 2012-02.

Nattrass, N. (2011). The new growth path: Game changing vision or cop-out? South African Journal of Science 107 (3/4), pp. 1-8.

Nhamo, G. (2013). Green economy readiness in South Africa: A focus on the national sphere of government. International Journal of African Renaissance Studies, 8 (1), 115-142.

Nhamo, G. ed. (2014). Breakthrough: Corporate South Africa in a Green Economy. Pretoria: Africa Institute of South Africa.,

Olivier, N. (2013). Personal Communication, Technical Coordinator, Green Building Council South Africa.

Panyathanakun, V., Tantayanon, S., Tingsabhat, C. \& Charmondusit, K. (2013). Development of eco-industrial estates in Thailand: Initiatives in the northern region community-based eco-industrial estate. Journal of Cleaner Production, 51, pp. 71-79.

Rogerson, C.M. (2014). Reframing place-based economic development in South Africa: The example of local economic development. Bulletin of Geography: Socio-Economic Series, 24, pp. 203-218.

Rogerson, J.M. \& Sims, S.R. (2012). The greening of urban hotels in South Africa: Evidence from Gauteng. Urban Forum, 23, pp. 391-407

Sakr, D., Baas, L., El-Haggar, S., \& Huisingh, D. (2011): Critical success and limiting factors for eco-industrial parks: Global trends and Egyptian context. Journal of Cleaner Production, 19, pp. 1158-1169.

Shi, H., Tian, J. \& Chen, L. (2012a). China's quest for eco-industrial parks, Part I, Journal of Industrial Ecology, 16 (1), pp. 8-10.

Shi, H., Tian, J. \& Chen, L. (2012b). China's quest for eco-industrial parks, Part II, Journal of Industrial Ecology, 16 (3), 290-292.

Singhala, S., \& Kapurb, A. (2002): Industrial estate planning and management in India—an integrated approach towards industrial ecology. Journal of Environmental Management, 66 (1), pp. 19-29.

Taddeo, R., Simboli, A. \& Morgante, A. (2012). Implementing eco-industrial parks in existing clusters: Findings from a historical chemical site. Journal of Cleaner Production, 32, pp. 22-29.

Tudor, T., Adam, E., \& Bates, M. (2007). Drivers and limitations for the successful development and functioning of EIPs (eco-industrial parks): A literature review. Ecological Economics, 61, pp. 199-207.

Van Leeuwen, M.G., Vermeulen, W.J.V. \& Glasbergen, P. (2003). Planning eco-industrial parks: An analysis of Dutch planning methods. Business Strategy and Environment, 12 (3), 147-162.

Veiga, L.B. E. \& Magrini, A. (2009). Eco-industrial park development in Rio de Janeiro, Brazil: A tool for sustainable development. Journal of Cleaner Production, 17, pp. 653669.

Vermeulen, A. (2014). Green ethos. Engineering News, 11-17 July, p. 30.

Wyeth, C. (2013): Interview. Senior Manager: Venture Operations and Venture Enablement, Sasol ChemCity,. Sasol Group Services, 5 July, Johannesburg.

Yu, C., de Jong, M. \& Dijkema, G.P.J. (2014). Process analysis of eco-industrial park development - The case of Tianjin, China. Journal of Cleaner Production, 64, pp. 464477.

Zhu, Q., \& Côté, R.P. (2004). Integrating green supply chain management into an embryonic eco-industrial development: A case study of the Guitang Group. Journal of Cleaner Production, 12, 1025-1035. 